\title{
ANALISIS PENGARUH GAYA KEPEMIMPINAN, KOMPENSASI DAN MOTIVASI TERHADAP KEPUASAN KERJA KARYAWAN di BANK BRI CABANG RANTEPAO TORAJA UTARA
}

\author{
Gisela Cantika Nosaria Palebangan. P \\ (giselapalebangan12@gmail.com) \\ Institutit Bisnis Keuangan Nitro Makasar \\ Jl. prof. Abdurahman Basalamah No.101
}

90231

\begin{abstract}
ABSTRAK
Kinerja bawahan juga dipengaruhi oleh perilaku pimpinan sebagai seorang atasan. Gaya kepemimpinan memiliki dampak yang signifikan terhadap sikap bawahan, perilaku dan kinerja bawahan. Efektivitas seorang karyawan akan sangat dipengaruhi oleh karakteristik pemimpinnya. Sedangkan kepuasan kerja dengan kinerja bawahan menunjukkan adanya saling keterkaitan yang erat dimana kepuasan kerja karyawan akan mempengaruhi kinerja dan loyalitasnya. Adanya pengaruh kekompetenan para karyawan dalam bekerja juga dipengaruhi oleh adanya kompensasi dan motivasi yang diberikan oleh pemimpin sebagai dorongan untuk meningkatkan kepuasan kerja kerja karyawan yang juga akan berpengaruh terhadap kualitas karyawan.
\end{abstract}

Kata kunci : gaya kepemimpinan, motivasi dan kompensasi, kepuasan kerja

\section{PENDAHULUAN}

\section{A. LATAR BELAKANG}

Gaya kepemimpinan seringkali menjadi hambatan bagi karyawan dalam menjalankan tugas dan kegiatan sehari-hari. Pemimpin di sini dituntut untuk mampu memahami motif dari karyawannya, sebab motif didasari oleh keinginan untuk memuaskan berbagai jenis kebutuhan yang pada gilirannya akan memengaruhi perilaku dan kinerja karyawan. Seorang pemimpin merupakan contoh, panutan, idola dan pembina bagi seluruh anggota organisasi yang dipimpinnya dalam peningkatan hasil kerja. Salah sasaran dalam pengelolaan sumber daya manusia pada fungsi manajemen organisasi berkaitan dengan masalah kepemimpinan. Seseorang yang telah ditunjuk sebagai pemimpin utnuk memimpin bawahannya, dialah yang harus menjalankan fungsi organisasi itu sendiri yang menentulan atas berhasil tidaknya suatu perusahaan. Kepemimpinan yang sukses menunjukkan bahwa pengelolaan suatu organisasi atau perusahaan berhasil dilaksanan dengan sukses juga. Setiap 
kemampuan dalam kepemimpinan harus melekat erat pada diri seorang pemimpin, apapun tanggungjawab yang harus diterimanya. Karena tanpa adanya kemampuan memimpin terlebih dalam hal mengelola sumber daya manusia, tidak memungkinkan seorang pemimpin berhasil dengan baik dalam melaksanakan tanggung jawabnya.

Keberhasilan suatu organisasi sangat dipengaruhi oleh kinerja pegawainya. Setiap organisasi maupun perusahaan akan selalu berusaha untuk meningkatkan kinerja bawahannya, dengan harapan apa yang menjadi tujuan perusahaan akan tercapai. Berbagai cara akan ditempuh oleh perusahaan dalam meningkatkan kinerja bawahannya, misalnya dengan melalui pendidikan, pelatihan, pemberian kompensasi yang layak, pemberian motivasi dan menciptakan lingkungan kerja yang kondusif.

Kepuasan kerja juga disinyalir berpengaruh terhadap kinerja bawahan, adapun kepuasan kerja menurut Handoko (2008) kepuasan kerja adalah keadaan emosional yang menyenangkan atau tidak menyenangkan dengan bagaimana para bawahan memandang pekerjaan mereka. Kepuasan kerja mencerminkan perasaan seseorang terhadap pekerjaannya dan bersifat dinamik. Setiap individu akan memiliki tingkat kepuasan yang berbeda beda sesuai dengan sistem nilai yang berlaku pada dirinya. Ini disebabkan karena adanya perbedaan pada masing masing individu. Kepuasan kerja perlu dimonitor oleh manajemen karena hal itu berpengaruh terhadap tingkat absensi, perputaran tenaga kerja, keluhan keluhan dan masalah masalah personalia lainnya.

Menurut (Handoko: 2012) Kapasitas produktif atau tidaknya bawahan tergantung pada motivasi, kondisi fisik pekerjaan, sistem kompensasi, desain pekerjaan, kepuasan kerja, aspek aspek ekonomis dan teknis dan keperilakuan lainnya .
Kepemimpinan di dalam Bank BRI cabang Ranteapo Toraja Utara kali ini mengalami perubahan yaitu adanya pergantian pemimpin tiap tiga tahun sekali. Perputaran kepemimpinan ini terkadang dirasakan membawa pengaruh langsung bagi tiap karyawan karena beberapa hal seperti rasa nyaman yang sudah terjalin dengan pemimpin lama atau karyawan merasa beban yang diberikan pemimpin bertambah banyak sehingga fenomena turn over terjadi didalam perusahaan Bank Bri Hal ini dipengaruhi oleh gaya kepemimpinan yang dibawa pemimpin atau dalam organisasi. Gaya kepemimpinan yang berbeda pada pribadi pimpinan cabang di Bank BRI Ranteapo dirasa menjadi salah satu faktor penting tercapainya target yang diharapkan perusahaan serta berpengaruh langsung pada kinerja karyawan Bank BRI cabang Rantepao. Setiap pimpinan cabang menerapkan gaya masing-masing untuk melaksanakan tugasnya serta membangun komitmen organisasional pada setiap karyawan, pimpinan yang terkenal otoriter atau kaku terkadang menekan bawahanya agar mencapai target yang diharapkan, ada juga yang menerapkan gaya partisipatif artinya pemimpin terjun langsung dalam sebuah event agar pemimpin menjadi salah satu bagian dari kinerja karyawan dan sebuah organisasi.

Disamping pengaruh gaya kepemimpinan dan kompensasi yang berjalan dinamis di dalam Bank BRI cabang Rantepao untuk masalah motivasi tiap karyawan dirasa penting untuk terjadinya komitmen organisasi karena tiap individu memiliki kenyakinan untuk melaksanakan pekerjaanya sesuai dengan dorongan yang muncul dari dalam diri tiap karyawan.

\section{B. Rumusan Masalah}

Berdasarkan uraian yang telah dijelaskan pada latar belakang diatas, maka rumusan masalah dalam penelitian ini adalah :

1. Apakah gaya kepemimpinan berpengaruh terhadap kinerja karyawan di Bank BRI cabang Rantepao Toraja Utara? 
2. Apakah kompensasi berpengaruh terhadap kepuasaan kerja karyawan di Bank BRI cabang Rantepao Toraja Utara?

3. Apakah motivasi berpengaruh dalam kinerja karyawan di Bank BRI cabang Rantepao Toraja Utara?

\section{Tujuan Penelitian}

1. Untuk mengetahui dan menganalisis pengaruh gaya kepemimpinan terhadap kinerja karyawan di Bank BRI Ranteapo Toraja Utara.

2. Untuk mengetahui dan menganalisis pengaruh kompensasi terhadap kepuasan kerja karyawan di Bank BRI cabang Rantapao Toraja Utara.

3. Untuk mengetahui dan menganalisis pengaruh motivasi dalam kinerja karyawan di Bank BRI cabang Rantepao Toraja Utara.

\section{KERANGKA TEORITIS}

\section{A. Sumber Daya Manusia (SDM)}

Menurut Sumarsono (2015, H 4) Sumber Daya Manusia (Human Resources) menurut beliau memiliki dua arti yang berbeda di antaranya adalah :

1) SDM merupakan suatu usaha kerja atau jasa yang memang diberikan dengan tujuan dalam melakukan proses produksi. Dengan kata lain Sumber Daya Manusia adalah kualitas usaha yang dilakukan seseorang dalam jangka waktu tertentu guna menghasilkan jasa atau barang.

2) Masih terkait dengan hal yang pertama, pengertian SDM yang kedua adalah dimana manusia mampu bekerja menghasilkan sebuah jasa atau barang dari usaha kerjanya tersebut. Mampu bekerja berarti mampu melakukan beragam kegiatan yang memiliki nilai ekonomis atau dengan kata lain adalah kegiatan tersebut bisa menghasilkan barang dan jasa untuk memenuhi kebutuhan hidup.
Dapat disimpulkan bahwa sumber daya manusia (SDM) adalah salah satu faktor yang sangat penting bahkan tidak dapat dilepaskan dari sebuah organisasi, baik institusi maupun perusahaan. SDM juga merupakan kunci yang menentukan perkembangan perusahaan. Pada hakikatnya, SDM berupa manusia yang dipekerjakan di sebuah organisasi sebagai penggerak, pemikir dan perencana untuk mencapai tujuan organisasi itu.

Oleh sebab itulah peran sumber daya manusia dalam organisasi/perusahaan itu sangat diperlukan sebagai unsur utama dan unsur pengendali keberhasilan suatu organisasi/perusahaan.

Adapun pengertian manajemen SDM menurut Rivai dalam Daga (2021: 2) Manajemen sumber daya manusia berhubungan dengan sistem rancangan formal dalam suatu organisasi untuk menentukan efektivitas dan efisiensi untuk mewujudkan sasaran siatu oraginasi .

\section{B. Gaya Kepemimpinan}

Setiap pemimpin pada dasarnya memiliki perilaku yang berbeda dalam memimpin para pengikutnya, perilaku para pemimpin itu disebut dengan gaya kepemimpinan. Gaya kepemimpinan merupakan suatu cara pemimpin untuk mempengaruhi bawahannya yang dinyatakan dalam bentuk pola tingkah laku atau kepribadian. Seorang pemimpin merupakan seseorang yang memiliki suatu program dan yang berperilaku secara bersama-sama dengan anggota-anggota kelompok dengan mempergunakan cara atau gaya tertentu, sehingga kepemimpinan mempunyai peranan sebagai kekuatan dinamik yang mendorong, memotivasi dan mengkordinasikan perusahaan dalam mencapai tujuan yang telah ditetapkan.

\section{Kompensasi}

Pengertian kompensasi menurut Hasibuan (2016: 118) berpendapat bahwa pengertian kompensasi adalah semua pendapatan yang berbentuk uang, barang langsung ataupun tidak langsung yang diterima karyawan dalam bentuk imbalan atas jasa yang diberikan kepada perusahaan. 
Kompensasi adalah segala sesuatu yang diterima baik berupa fisik maupun nonfisik. Bisa juga berarti seluruh imbalan yang diterima oleh seorang pekerja/karyawan atas jasa atau hasil dari pekerjaannya dalam sebuah perusahaan dan kompensasi yang diterima dapat berupa uang, barang, secara langsung maupun tidak langsung. Kompensasi biasanya diberikan oleh atasan kepada karyawannya sebagai tanda bahwa karyawan tersebut telah bekerja dengan keras.dan hal tersebut bisa menjadi motivasi yang baik untuk para karyawan agar mau bekerja lebih keras lagi untuk kemajuan perusahaan. Dan dengan itu pemberian kompensasi juga bisa menjadi sebuah sistem reward yang bagus di dalam perusahaan. Hal ini akan membentuk karyawan yang loyalitas terhadap terhadap pekerjaanya. Memiliki karyawan yang loyalitas pastilah hal yang diinginkin semua perusahaan karena dengan memiliki karyawan yang mempunyai loyalitas tinggi maka daya saing perusahaan pun bisa dikatakan meningkat .

adapun pengertian loyalitas menurut Siagian dalam Daga ( 2021:3), loyalitas adalah suatu kecenderungan karyawan untuk tidak pindah ke prusahaan lain sebab loyalitas dapat mempengaruhi kenyaman karyawan untuk bekerja pada suatu perusahaan .

\section{Motivasi}

Menurut Handoko (2012 :252)

"Motivasi adalah keadaan dalam pribadi seseorang yang mendorong keinginan individu untuk melakukan kegiatan-kegiatan tertentu guna mencapai tujuan".

Dengan adanya motivasi yang diberikan oleh seorang pemimpin terhadap karyawannya yang merupakan bentuk dorongan yang secara tidak langsung akan membuat karyawan merasa dibutuhkan dan merasa dihargai dalam pekerjaanya karena adanya kepercayaan yang diberikan pemimpin bahwa mereka pasti sanggup untuk melakukan tugas-tugasnya . Maka hal ini akan meningkatkan loyalitas karyawan dalam perusahaan. Hal ini akan membentuk karyawan yang loyalitas terhadap terhadap pekerjaanya. Memiliki karyawan yang loyalitas pastilah hal yang diinginkin semua perusahaan karena dengan memiliki karyawan yang mempunyai loyalitas tinggi maka daya saing perusahaan pun bisa dikatakan meningkat .

adapun pengertian loyalitas menurut Siagian dalam Daga ( 2021:3), loyalitas adalah suatu kecenderungan karyawan untuk tidak pindah ke prusahaan lain sebab loyalitas dapat mempengaruhi kenyaman karyawan untuk bekerja pada suatu perusahaan .

Motivasi mempersoalkan bagaimana caranya mengarahkan daya dan potensi bawahan, agar mau bekerja sama secara produktif berhasil mencapai dan mewujudkan tujuan yang telah ditentukan. Kemampuan seorang manajer dalam memotivasi bawahannya akan mempengaruhi efektifitas manajer, bawahan dan perusahaann. Manajer yang dapat melihat motivasi sebagai suatu sistem akan mampu meramalkan perilaku dan kinerja bawahannya. Motivasi dibagi menjadi dua jenis yaitu :

1) Motivasi intrinsik

Motivasi ini adalah pendorong kerja yang bersumber dari dalam diri pekerja sebagai individu, berupa kesadaran mengenai pentingnya atau manfaat akan pekerjaan yang dilaksanakan.

2) Motivasi ekstrinsik

Motivasi ini adalah pendorong kerja yang bersumber dari luar diri pekerja sebagai individu berupa suatu kondisi yang mengharuskannya melaksanakan pekerjaan secara maksimal.

\section{METODOLOGI PENELITIAN}

\section{A. Waktu dan Lokasi Penelitian}

Penelitian ini dilakukan pada PT. Bank Rakyat Indonesia (persero), Tbk Cabang Rantepao Toraja Utara yang berlokasi di Jl. Jend. Achmad Yani No. 96 Rantepao. Adapun waktu yang digunakan 1 (satu) bulan.

\section{B. Jenis dan Sumber Data}

1. Jenis Data 
Jenis data yang digunakan dalam penelitian ini adalah data kualitatif, dimana data kualitatif adalah suatu data yang berbentuk data maupun kalimat. Data ini diperoleh dari hasil wawancara yang terkait dengan penelitian.

2. Sumber Data

Sumber data pada penelitian ini berupa data primer yang berasal dari wawancara langsung dan observasi dengan informan peneliti.

\section{Metode dan Teknik Pengumpulan Data}

\section{Metode Pengumpulan Data}

Metode pengumpulan data yang

digunakan yaitu :

a. Wawancara

Wawancara merupakan alat cheking atau pembuktian terhadap informasi atau keterangan yang diperoleh sebelumnya. Menurut Esterberg wawancara adalah pertemuan dua orang untuk bertukar informasi dan ide melalui tanya jawab, sehingga dapat dikontruksikan makna dalam suatu topik tertentu (Sugiyono, 2010:231). Teknik wawancara yang digunakan dalam penelitian kualitatif adalah wawancara mendalam (Indepth interview) adalah proses memperoleh keterangan-keterangan untuk tujuan penelitian dengan cara tanya jawab sambil bertatap muka antara pewawancara dengan informan atau orang yang diwawancarai, atau tanpa menggunakan pedoman (guide) wawancara.

b. Observasi

Observasi merupakan kegiatan yang melibatkan seluruh kekuatan indera seperti pendengaran, penglihatan, perasa, sentuhan dan cita rasa berdasarkan pada fakta-fakta peristiwa empiris. Prinsip umum dalam melakukan observasi adalah pengamat tidak memberikan perlakuan tertentu kepada subjek yang diamati, melainkan membiarkan subjek yang sedang diamati berucap dan bertindak sama persis dengan kegiatan mereka sehari-hari (Anggito dan Setiawan, 2018:142).

\section{Teknik Pengumpulan Data}

Teknik yang digunakan dalam penelitian ini dapat diuraikan sebagai berikut :

a. Data kata-kata (verbal) berupa apa yang dikatakan informan tentang pengaruh gaya kepemimpinan, kompensasi dan motivasi terhadap kinerja dan kepuasan kerja karyawan pada PT Bank Rakyat Indonesia (Persero), Tbk Cabang Rantepao Toraja Utara.

b. Data non verbal merupakan apa yang dipikirkan, dipercaya, diketahui dan disikapi oleh informan dalam kegiatannya.

c. Data pustaka berupa pengumpulan data dengan cara menelaah dan mempelajari literatur-literatur, buku dan bahan pustaka lainnya yang menyangkut teori-teori yang relevan dengan masalah yang akan dibahas.

d. Data fotografi membantu memberikan gambaran sesuai perilaku dan membuktikan bahwa adanya wawancara yang dilakukan peneliti.

\section{Informan Peneliti}

Pada penelitian kualitatif, tidak dikenal adanya populasi dan sampel tetapi dinamakan informan. Informan adalah orang yang diberikan pertanyaan untuk mendapatkan informasi mengenai fokus penelitian. Informan ditentukan dengan teknik purvosive, yaitu teknik penentuan subjek (informan) yang berdasarkan kriteria dan tujuan dari penelitian ini. Kriteria ini ditentukan oleh peneliti, dimana yang dipilih peneliti adalah salah satu karyawan di bidang Account Officer atau Analis Kredit PT Bank Rakyat Indonesia (Persero), Tbk Cabang Rantepao Toraja Utara dengan tidak berdasarkan jenis kelamin dan mereka siap menjadi informan. Informan yang digunakan adalah 1 (satu) orang dan memungkinkan 
adanya penambahan jika tujuan penelitian belum tercapai.

Tahapan untuk memperoleh informan adalah :

1. Peneliti mencari informasi karyawan Bank BRI sesuai kebutuhan peneliti.

2. Peneliti kemudian menyeleksi calon informan tersebut dengan melihat kesesuaian kriteria, dan juga berdasarkan sifat keterbukaan informan.

3. Peneliti mengajukan pertanyaan untuk kesediaan mereka melakukan wawancara.

\section{E. Instrumen Penelitian}

Instrumen penelitian yang digunakan berbentuk pertanyaan terbuka, pertanyaan dimulai dengan identifikasi informan. Dimana pertanyaan utama merupakan pertanyaan yang mengarah pada hubungan gaya kepemimpinan, motivasi dan kompensasi terhadap peningkatan loyalitas kinerja dan kepuasan kerja karyawan . Adapun hal yang ingin ditanyakan :

1. Apakah gaya kepemimpinan yang dilakukan oleh Manager Cabang Bank berpengaruh terhadap kinerja karyawan di PT Bank Rakyat Indonesia (Persero), Tbk Cabang Rantepao?

2. Apakah kompensasi berpengaruh terhadap kepuasan kerja karyawan di PT Bank Rakyat Indonesia (Persero), Tbk Cabang Rantepao?

3. Apakah motivasi berpengaruh dalam kinerja karyawan di PT Bank Rakyat Indonesia (Persero), Tbk Cabang Rantepao ?

Keseluruhan inti pertanyaan tersebut akan dihubungkan dan diselaraskan berdasarkan teori-teori yang ada.

\section{F. Defenisi Operasional}

1. Sumber daya manusia (SDM) merupakan manusia yang dipekerjakan di sebuah organisasi/perusahaan sebagai penggerak, pemikir dan perencana untuk mencapai tujuan organisasi itu.

2. gaya kepemimpinan adalah kemampuan seorang pemimpin dalam mengarahkan, mempengaruhi, mendorong dan mengendalikan karyawannya untuk bisa melakukan sesuatu pekerjaan atas kesadarannya dan sukarela dalam mencapai suatu tujuan tertentu.

3. Kompensasi adalah segala sesuatu yang diterima baik berupa fisik maupun nonfisik. Bisa juga berarti seluruh imbalan yang diterima oleh seorang pekerja/karyawan atas jasa atau hasil dari pekerjaannya dalam suatu perusahaan. Adapun indikatornya yaitu :

4. Motivasi mempersoalkan bagaimana caranya mengarahkan daya dan potensi karyawan, agar mau bekerja sama secara produktif agar berhasil mencapai dan mewujudkan tujuan yang telah ditentukan.

5. kepuasan kerja atau kepuasan karyawan adalah ukuran dari tingkat kepuasan pekerja dengan jenis pekerjaan mereka yang berkaitan dengan sifat dari tugas pekerjaannya, hasil kerja yang dicapai, bentuk pengawasan yang diperoleh maupun rasa lega dan menyukai pekerjaan yang ditekuninya.

\section{G. Metode Analisis Data}

1. Pendekatan penelitian Penelitian ini dilakukan dengan menggunakan metode penelitian kualitatif, dimana penelitian kualitatif adalah metode penelitian yang berlandaskan pada filsafat post positivisme atau enterpretif, yang digunakan untuk meneliti pada kondisi objek kunci, teknik pengumpulan data dilakukan secara triangulasi (gabungan observasi, wawancara dan dokumentasi), data yang diperoleh cenderung data kualitatif, analisis data bersifat induktif/kualitatif, dan hasil penelitian kualitatif bersifat untuk memahami makna, memahami keunikan, mengkonstruksi fenomena, dan menemukan hipotesis (Sugiyono, 2017:9).

2. Pendekatan kualitatif naratif Pendekatan kualitatif naratif merupakan pendekatan yang dilakukan dengan mempelajari perjalanan kehidupan dari satu orang atau lebih yang kemudian dirangkum dan disusun oleh penelitian 
menjadi satu laporan yang naratif dan

kronologis (Sugiyono, 2017:162).

\section{KESIMPULAN}

Berdasarkan hasil analisis dan pembahasan yang dilakukan maka dapat disimpulan bahwa gaya kepemimpinan dengan melibatkan motivasi dan kompensasi terhadap karyawan berpengaruh positif dan signifikan didalam kinerjanya . Seorang pemimpin merupakan contoh, panutan, idola dan pembina bagi seluruh anggota organisasi yang dipimpinnya dalam peningkatan hasil kerja. Salah sasaran dalam pengelolaan sumber daya manusia pada fungsi manajemen organisasi berkaitan dengan masalah kepemimpinan. Seseorang yang telah ditunjuk sebagai pemimpin untuk memimpin bawahannya, dialah yang harus menjalankan fungsi organisasi itu sendiri yang menentukan atas berhasil tidaknya suatu perusahaan. Kepemimpinan yang sukses menunjukkan bahwa pengelolaan suatu organisasi atau perusahaan berhasil dilaksanan dengan sukses juga. Dan karyawan yang berkualitas adalah hasil dari gaya kepemimpinan yang sukses .

\section{DAFTAR PUSTAKA}

Handoko, T. Hani. 2012. Manajemen Personalia dan Sumber Daya Manusia.

Yogyakarta. BPFE

Hasibuan, Melayu Sp. 2016. Kompensasi dan Motivasi ; dasar peningkatan produktivitas. Cetakan ke 14. Jakarta : PT. Bumi Aksara

Kartono, Kartini, 2017 : Pemimpin dan

Kepemimpinan. Jakarta : PT. Raja

Grafindo Persada.

Laffal, Muchinsky. 2014. Psychology Applied to Work. Ed 16. Thomson Wadsworth USA.

Luthans. F. 2013. Perilaku Oragnisasi dan

Kepuasan Kerja (ed.12). Andi,

Yogyakarta
Robbins S.P, 2015. Perilaku Organisasi :

Konsep, Kontroversi dan Aplikasi, PT.

Prehalindo Persada, Jakarta

Daga, R (2021) Analisis Kompetensi

Karyawan Berdasarkan Gender Pada

PT. Bank Rakyat Indonesia

(PERSERO), Tbk, Cabang Soppeng

Daga, R. (2021). Faktor-Faktor Yang

Mempengaruhi Loyalitas Karyawan

Pada pt. Bank Syariah Mandiri Kantor

Cabang Makassar

Sutrisno, Edy. 2013. Manajemen Sumber

Daya Manusia, Cetakan Kelima.

Yogyakarta: Prenada Media 